\title{
Determinants of Dividend Payout Decisions: A Dynamic Panel Data Analysis of Turkish Stock Market
}

\author{
Faruk Bostanci ${ }^{1}$, Eyup Kadioglu ${ }^{2, * \mathbb{C}}$ and Guven Sayilgan ${ }^{3}$ \\ 1 Isiklar Holding A.S., Tandogan, Ankara 06580, Turkey; faruk.bostanci@gmail.com \\ 2 Investor Compensation Center, Capital Markets Board of Turkey, Ankara 06530, Turkey \\ 3 Department of Management, Ankara University, Ankara 06590, Turkey; guven.sayilgan@ankara.edu.tr \\ * Correspondence: eyup.kadioglu@gmail.com; Tel.: +90-312-292-8013
}

Received: 29 August 2018; Accepted: 14 November 2018; Published: 20 November 2018

check for updates

\begin{abstract}
This study analyzes the firm-specific factors affecting the dividend payout decisions of the companies whose shares are traded on the Borsa Istanbul stock exchange. To this end, the dynamic panel regression is applied to 853 observations of yearly average of 106 companies listed on the Borsa Istanbul between 2009 and 2015. According to results from the Arellano-Bover/Blunder-Bond two-step system generalized method of moments, a statistically significant positive effect on dividend payout was found in the relationship between the dividend payout of the previous year, the company's return on equity and the market value/book value ratio, liquidity and the company's size. The demonstration of a positive relationship between dividend payout and return on equity supports the free cash flow hypothesis and the positive relationship with the previous year's dividend payout ratio supports the dividend smoothing hypothesis for Turkey.
\end{abstract}

Keywords: dividend; free cash flow hypothesis; dividend smoothing hypothesis; dividend irrelevance hypothesis; dynamic panel; Borsa Istanbul

JEL Classification: G10; G30; G35; G38

\section{Introduction}

Until the middle of the 20th century it was unchallenged and generally accepted that dividend payout had a positive effect on a company's value. The "irrelevance hypothesis" developed by Miller and Modigliani (1961) shook up this established confidence. According to the irrelevance hypothesis, the profit generated by a company, under conditions of a fully competitive market, must not have a positive effect on the company's value. A company's value can be increased only if the company invests its retained earnings into projects which provide higher yield. Therefore, there is no relationship between the company's value and dividend payout. However, contrary to the irrelevance hypothesis, in the real-world investors continue to request dividend payout with the expectation that it will add positively to the company's value. Companies' dividend payout decisions are one of the most studied subjects in the field of finance.

After the work of Miller and Modigliani (1961), many hypotheses and theories were developed to explain the factors determining dividend payout decisions and the relationship between dividend payout decisions and a company's worth. It is not possible to discuss one existing common result of these academic studies. Black (1976) identified this situation as the 'dividend puzzle', and Brealey and Myers (2002) counted this puzzle among the top ten unsolved problems of finance.

Efforts are still being made to solve the aforementioned enigma regarding the dividend payout with the aim of reaching more precise results using different methodologies and data. These studies are 
predominantly related to developed markets, although studies using data from developing markets and international comparative studies are becoming more common.

In Turkey, being a candidate for the EU, many regulations including corporate governance principals on companies and capital markets are put into practice so as to reduce gap Turkey and EU. In 2003 corporate governance principals have entered in Turkey with the "comply or explain" approach by imitating principals or codes from UK and OECD. In 2012 the "comply or explain" approach turned in to the compliance rules. Similarly, many regulations from developed market including dividend policy of corporation are amended in the Turkish Commercial Code of 2012. Given the importance of new regulations in Turkey which are mainly adopted from developed market, it should be investigated as to whether the empirical results are in line with developed market.

Although, dividend smoothing hypothesis Lintner (1956) is quoted widely by studies in this field. There are very few studies which empirically test the hypothesis in the literature. To test the effect of previous year's dividend payout on the current year's dividend payout requires an advanced econometric analysis technique like dynamic panel regression that this study is utilized. By using 7 years of data from companies whose shares were traded on the Borsa Istanbul between 2009 and 2015, the company specific factors are analyzed which affects dividend payout decisions of listed companies between 2010 and 2016. The size of the company, profitability, liquidity, age, shareholder structure, debt ratio, market value to book value ratio and previous year's dividend payout were taken as the explanatory variables in the analysis. As in similar studies, dividend payout per share is used as a dependent variable representing the dividend payout decision. However, this study also considers dividend paid out as shares (stock dividends) alongside dividend paid out as cash when calculating dividend payout per share; the first time, as far as we know, that this has been done in a study of dividend payout decisions in Turkey. The second original aspect of this work is related to the methodology used: the coefficients of the independent variables are estimated by Arellano-Bover/Blundell-Bond, one of the dynamic panel data methods, two-step system generalized method of moments (GMM) as it also used by Ahmed and Javid (2008); Maldajian and Khoury (2014) and Patra et al. (2012).

According to the results of the two-step dynamic panel regression; the previous year's dividend payout per share, the company's return on equity and the market value to book value ratio, size in terms of market capitalization and the liquidity has positive effect on dividend payout; while no statistically significant effect on dividend payout detected from age, family control or debt ratio. The results show that the determinant of the dividend payout in Turkish stock market is not different from developed markets. Therefore, the theories and the model are applicable for Turkey as an example of emerging markets.

The emergence of a positive relationship between dividend payout and return on equity supports the free cash flow hypothesis and the positive relationship with the previous year's dividend payout ratio supports the dividend smoothing hypothesis.

The next section of this study is a summary of the literature, the third section is an explanation of the data set and methods, and the fourth section explains the empirical results. The fifth and final section consists of conclusions and recommendations.

\section{Literature Review}

Before Miller and Modigliani (1961)'s paper, many economists thought that a company's value increases as dividend payout increases. Almost everyone agreed that a company must pay out dividends for existential reasons and that the shares of high dividend companies should be sold at a high price (Frankfurter and Wood 1997). The basis of this thinking depended on the assumption that the current value of the company is a discounted form of the company's future profits. Contrary to this assumption, Miller and Modigliani (1961), suggest that the value of the company is not affected by dividend payout; deciding to give the profit only as dividends or leave it within the company as determined by the company's investments with no change in investment policy has no effect on 
its own. Miller and Modigliani (1961)'s model's result forms the basis of the discussions/study of dividends over the past 50 years in the finance literature (Al-Malkawi et al. 2010).

Models and theories developed after that of Miller and Modigliani (1961), either implicitly or explicitly, removing or relaxing the assumptions of the their model. Empirical and theoretic works on the subject, for the most part, have tried to explain the reasons for the market imperfection related to dividend payout that appeared due to asymmetric information, taxes, and transaction costs.

The first sets of asymmetric information-based models are the agency hypothesis, the pecking order hypothesis and the signaling hypothesis. The basics of the relationship between the agency problem and dividend payout is based on the work of Easterbrook (1984) and Jensen (1986). According to Easterbrook (1984), dividend payout reduces the agency cost. Because dividend payout forces company managers to provide cash from the market, it means that the market actors must keep a close eye on the company. The pecking order hypothesis, whose approach is the antithesis of the agency hypothesis, is based on work by Donaldson (1961) and Myers and Majluf (1984). According to this hypothesis, managers first prefer the internal sources, if the internal financing is not sufficient, then managers would have to move to the external sources. To access the external funds, they will issue debt. If issuing more debt is no longer practical to raise the funds, then issuing the equity is the final option. The signaling hypothesis assumes that dividend payout decision has the effect of a signal sent out from within the company when information is asymmetric. According to the signaling hypothesis developed by Bhattacharya (1979), managers have more knowledge of the company's investments than those shareholders who are outside the company and use the company's dividend payout decisions as a means to convey this information to the outsider. In works that came after Bhattacharya (1979), which see dividend payout as a means of providing information from inside the company to the outside (John and Williams 1985; Miller and Rock 1985), the view is that the managers on the inside have more information about the company's future cash flow than outside investors or partners and reflect this information in dividend payout decisions.

A second group of models emerge when the assumption, "there are no tax differentials either between distributed and undistributed profits or between dividend and capital gain", is removed from the model by Miller and Modigliani (1961, p. 412). Indeed, dividend earnings are usually taxed more than capital gains. It can be assumed that investors who faced with different tax rates would prefer to reduce their tax burdens as much as possible. For example, according to the clientele effect hypothesis, if the dividend yield is taxed more, investors who do not need cash tend to prefer companies that do not pay out dividends rather than those that do, suggesting that investors in the other case tend to prefer cash dividend paying companies. Hence, this explains the market response to changes in dividend payout: when the dividend payout decision is changed, those investors who wish to reduce their tax burden will rearrange their portfolios.

The third group of models have arisen with the loosening of the zero cost assumption of the Miller and Modigliani (1961) model which assumes that shareholders do not make a distinction between cash dividend and capital gain because they can obtain cash when they need it by selling the shares they hold, on the market without any cost. However, trading on the market is not cost-free, shareholders face concealed or unconcealed costs when they are trading. Transaction costs are the expenses incurred during the purchase or sale of shares (commission fees, etc.). In some cases, a lack of depth/liquidity in the market has the effect of lowering the price of large quantity sales (Papadopoulos and Charalambidis 2007).

Another area where transaction costs affect the dividend payout is the cost of the issuing of new shares to meet the company's financing needs. If the cost of providing external financing for companies is high, they have a higher tendency to leave their earnings within the company. In this case there will be a negative relationship between dividend payout and transaction costs. However, in practice, companies often pay out dividends on the one hand, while on the other hand issuing new shares and borrowing because other factors affecting dividend payout are dominant (Al-Malkawi et al. 2010). 
On the other hand, Easterbrook (1984) argues that if the company's cash position is insufficient for cash dividend, the need for cash will be met from the market, which will be reflected as an extra cost to the company paying out dividends. Even if there is no transaction cost for shareholders, cash dividend payout comes at a cost to the company. Since this cost will reduce the amount of profit and therefore, negatively affect the value of share, the effect of the transaction costs on the dividend is not clear. In empirical studies, it has been shown that transaction costs have little effect on dividend decisions (DeAngelo et al. 2009).

According to the Lintner (1956) model, which accepted as the first empirical study on dividend payout, managers are reluctant to change the level of dividend payout, and unwilling to increase their dividend payout ratios even if the profit performance is very high. They only increased the dividend payout ratio if they think this ratio to be sustainable in the future. Future profit forecasts are currently one of the most effective factors for dividend payout decisions. Similarly, managers are extremely reluctant to reduce dividend payout and will only reduce the dividend payout if they think the unfavorable conditions will only be very short term.

In the Lintner (1956) model, the dividend payments are a function of current period profit, past dividend payments, the target dividend payout ratio of the company, and the rate of approach of the current dividend payments to the target dividend amount. According to this model, the past dividend payout ratio along with the current period's profit are the most important determiners of the dividend payout ratio. Lintner (1956) observed that companies increased their dividend payout ratios and were reluctant to reduce them when they predicted a sustainable growth in future cash flows. This is called the "dividend smoothing hypothesis" (Baker 2009).

According to the bird in hand theory laid out in the background of Gordon $(1959,1963)$ and Walter (1963)'s work, in a world of uncertainty and information asymmetry investors prefer the present earnings (bird in hand), dividend payments, to future earnings (two birds in the bush), capital gains. For this reason, when everything else is constant, more dividend payout increases the market price of the company, in other words, it increases the value of the company. The high dividend payout share today reduces the cost of the capital, thereby reducing the uncertainty about the future and thus increases the value of the share. The current high dividend payout removes uncertainty about future cash flows, reduces cost of capital and increases the value of the company (Al-Malkawi et al. 2010).

Miller and Modigliani (1961) criticize this approach, suggesting that the company is fundamentally driven by its cash flows, not by the way it distributes its earnings. Bhattacharya (1979) describes the bird in hand theory as an illusion and suggests that a company's cash flow risk will affect that company's dividend payments but not decrease the risk by increasing dividend payments. A company's cash flows are reflected to its dividend payments. Increasing dividend payments alone cannot reduce the company's risk. As the company's risk increases, dividend payouts can be expected to decline. Increasing the dividend payouts does not have a diminishing effect on a company's risk.

Grullon et al. (2002) developed the "maturity hypothesis" which argues that as companies mature, their investment/growth opportunities diminish, and as a result the expectations for return on their investments will fall. As the expected of return declines, companies distribute cash from their previous investments to their shareholders as dividends rather than turning them into new investments. Therefore, a feature of mature companies is a higher rate of dividend payout. According to this hypothesis, dividend payout yields two pieces of information: First, the systematic risk of the company is reduced. Second, the company's investment opportunities have narrowed, and in the future, it cannot make high investments. If the market shows a positive response to the dividend news, it means that the market prefers reduced risk to reduced profit.

The study of Javakhadze et al. (2014) show that Lintner (1956) dividend smoothing model works internationally, but with cross-sectional differences. Andres et al. (2015) also found partial adjustment in dividend is valid in both dividends and total payouts. Notwithstanding the small number of empirical studies which support the irrelevance hypothesis (Bernstein 1996; Black and Scholes 1974; 
Miller and Rock 1985), there are a number of studies showing that the dividend payout decisions of the company are influential on share prices (Al-Malkawi et al. 2010; Kadioglu et al. 2015).

In testing signaling hypothesis, Benartzi et al. (1997) did not come across any meaningful evidence that changes in the dividends provided any information related to future profitability. Kadioglu and Öcal (2016), working in Turkey, reached a similar result. Pettit (1977) and Baker and Wurgler (2004)'s studies reached results which support the clientele effect hypothesis. In Lasfer (1996)'s analysis he found that companies that pay out more cash dividends are preferred by investors in the lower income group.

Apart from theoretical studies, there are several empirical studies that generally investigate the factors affecting dividend payout at the company level.

Table 1 below summarizes results of some empirical studies which aim to find out effect of internal factors on dividend payout. The $+/-$ signs in the table shows positive or negative effect of the internal factor like debt, liquidity, shareholder structure (controlled by a family or not), maturity (age), market value/book value ratio, profitability, size, the previous year's dividend payout and current dividend payout.

Table 1. Effect of Internal Factors on Dividend Payout (Empirical Studies).

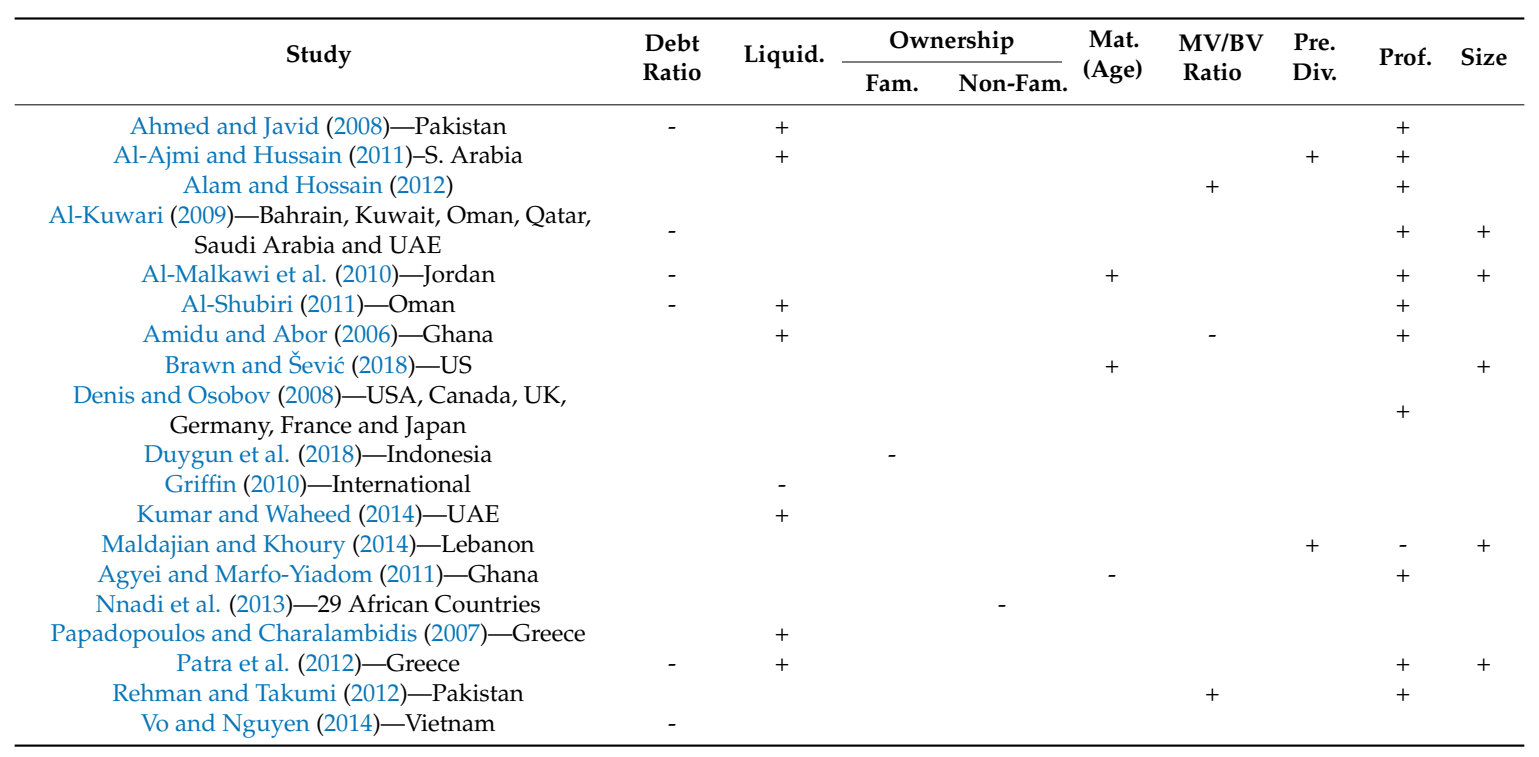

As seen from Table 1, empirical studies found a negative relationship between dividend payout and level of debt. Firms that have higher debts, payout lower dividend since earnings paid for debt servicing. The profitability, liquidity and size mainly affect the dividend payout positively. Firms that have higher profits, liquidity and bigger size, payout more dividends. Some of the studies found that family-owned companies pay lower dividend and previous years' dividend payout positively influence current dividend payout.

The studies on Turkish stock market takes in to account only cash dividend and many of them used data of companies which are prepared their financial statements according to Turkish accounting standards and data of regulated period (listed companies must distribute a fraction of their earnings as a dividend up to 2008). Adaoglu (2008) analyzed whether dividend payout is declining over time and the effect of the size on dividend payout using the data containing period of 1986-2007. He found that dividend payout decreased over time and bigger firm distributes more dividends. Ersoy and Çetenak (2015) investigated the impact of ownership concentration on the dividend payout policy by using data set data for the period from 2004 to 2009 and found the higher debt financing and market value to book value ratio effect the dividend payout negatively, whereas the higher profit lead the higher dividend payout. Kuzucu (2015) and Yildiz et al. (2014) analyzed the firm-specific factors affecting the dividend decisions and they both used panel data for the period from 2006 to 2013 
and from 2003 to 2010 respectively by utilizing panel regression. His finding confirms the result of Duygun et al. (2018) and Al-Najjar and Kilincarslan (2016), and he also found the size and age positively affect the dividend payout. Yildiz et al. (2014) found liquidity, size and profitability have a positive impact on the dividend payout.

\section{Data and Methodology}

\subsection{Data}

The data from 2009 to 2015 was used to analyze the dividend payout decisions of companies whose shares were traded on the Borsa Istanbul stock exchange between 2010 and 2016. Since the financial statements of the listed companies in Borsa Istanbul are fully compatible with IFRS after 2009, the sample covering period from 2009 to 2015 is selected to be compatible with other international studies, besides, mandatory dividend regulations abolished by Turkish capital market authority starting from 2009. The following variables, which are considered to affect dividend payout decisions, have been obtained from the companies' yearly financial statements prepared via independent auditing in accordance with the IFRS (dated December 31st) and acquired with the help of the Finnet Financial Analysis program. The data related to the companies, which was not included in the financial statements (i.e., year founded, ownership structure, etc.), was taken from the Public Disclosure Platform (www.kap.org.tr) and the companies' websites; while the information related to dividend payout amounts made in the form of cash and shares was retrieved from Is Yatirim Menkul Degerler A.S. (www.isyatirim.com.tr).

The average number of companies whose shares were listed on the Borsa Istanbul between 2010 and 2016 is 389. Just as in previous similar work (Adaoglu 2008; Al-Najjar and Kilincarslan 2016; Sayllgan et al. 2006), financial institutions (banks, insurance companies, factoring and leasing companies, brokerage houses, securities investment trusts) whose investment and dividend payout decisions are subject to different regulatory provisions from other companies. Additionally, companies that have paid out dividends for less than three years in whole period have been excluded from the sample. After these exclusions, the remaining sample sets of the observations consist of 94 companies for 2009, 96 for 2010, 100 for 2011, 103 for 2012, 111 for 2013, 117 for 2014, 117 for 2015 and 115 for 2016. There is a total of 853 (an average of 106) companies observed during the years in question.

\subsection{Variables and Descriptive Statistics}

The dividend payout per share is used as a dependent variable in the study to represent the dividend payout decision.

When calculating the dividend payout ratio in previous studies, it seems that dividend payout only as cash was considered. In this study, taking dividend payout as cash into account along with cash increase through stock dividend (the following dependent variable was calculated ${ }^{1}$ ):

$$
\text { Dividend Payout }(\text { Cash }+ \text { Stock }) \text { Per Share }=\frac{\text { Cash Div. }+ \text { Stock Div. } * \text { Price of Share }}{\text { Paid in Capital }}
$$

1 Price of share in the formula 1 is the market price at the dividend payment date. 
In our study, there are eight factors which were considered to affect the dividend payout and constitute the independent variables in the model. The independent variable data is calculated as:

Size $(R C A P)^{2}=1$ Billion $\times(\text { Market Capitalization })^{-1}$

Profitability $(P R O)=$ Net Profit/Equity

Liquidity $(L I Q U)=$ Liquid Assets/Short Term Liabilities

Maturity $(A G E)=$ Year of Financial Report-Year of Founding of Company

Equity Structure $=$ If the company is under family $\operatorname{control}^{3} F A M=1$, If not $F A M=0$

Debt $(D E B T)=$ Short and Long-Term Liabilities $/$ Total Assets

MV/BV $(\mathbf{M V})=$ Market Value $/$ Book Value calculated as of $31 / 12$

Pre. Div. Payout $\left(D P S_{t-1}\right)=$ The previous year's dividend payout per share

The variable related summary descriptive statistics that will be used in this study are shown on Table 2 below.

Table 2. Descriptive Statistics of Variables.

\begin{tabular}{cccccc}
\hline Variable & $N$ & Average & St. Dev. & Minimum & Maximum \\
\hline DPS & 853 & 1.8162 & 12.1190 & 0.0000 & 288.7700 \\
RCAP & 853 & 2.0755 & 4.8134 & 0.0018 & 44.9644 \\
$\boldsymbol{P R O}$ & 853 & 0.1281 & 0.1302 & -0.5970 & 0.8944 \\
LIQU & 853 & 2.3043 & 12.3775 & 0.0003 & 259.3688 \\
AGE & 853 & 36.3939 & 16.3584 & 2.0000 & 105.0000 \\
FAM & 853 & 0.5393 & 0.4987 & 0.0000 & 1.0000 \\
DEBT & 853 & 0.4008 & 0.2190 & 0.0028 & 0.9091 \\
$\boldsymbol{M} \boldsymbol{V}$ & 853 & 1.8855 & 2.2522 & 0.2319 & 22.3732 \\
\hline
\end{tabular}

To see the magnitude of co-movement between variables, the correlation matrix is established in Table 3 below.

Table 3. Correlation Matrix between Variables.

\begin{tabular}{ccccccccc}
\hline Variable & DPS & RCAP & PRO & LIQU & AGE & FAM & DEBT & MV \\
\hline DPS & 1 & & & & & & & \\
$\boldsymbol{R} \boldsymbol{C A P}$ & -0.0564 & 1 & & & & & & \\
$\boldsymbol{P R O}$ & 0.0821 & -0.2185 & 1 & & & & & \\
$\boldsymbol{L I Q U}$ & -0.0156 & -0.0185 & -0.036 & 1 & & & & \\
$\boldsymbol{A} \boldsymbol{G} \boldsymbol{E}$ & 0.0177 & -0.2493 & -0.0228 & -0.0404 & 1 & & & \\
$\boldsymbol{F A M}$ & -0.0031 & 0.1092 & 0.027 & 0.0893 & -0.1623 & 1 & & \\
$\boldsymbol{D E B T}$ & 0.0089 & -0.004 & -0.0056 & -0.2642 & -0.0461 & 0.0883 & 1 & \\
$\boldsymbol{M} \boldsymbol{V}$ & 0.0741 & -0.1237 & 0.3696 & -0.0471 & 0.0254 & -0.0214 & 0.1238 & 1 \\
\hline
\end{tabular}

As seen from Table 3, the correlation coefficients between the variables are low. It appears that the maximum correlation is between the $M V$ variable and the $P R O$ variable (0.37).

3 Family control is defined as a family having a control over the company (through majority of the share or privileged shares which confer control) either directly or indirectly (through other companies).

2 In order to improve the regression's appearance and to facilitate interpretation, the mathematical inverse of the market capitalization variable used to represent the sizes of the companies was taken and multiplied by one billion as in studies by Okumuş (2002) and Günalp and Çelik (2004). Therefore, the results of this variable should be interpreted accordingly. 


\subsection{Methodology}

The following equation is applied to analyze the factors affecting the dividend payout decisions of companies. It aims to estimate the independent variables' effect on dividend payout per share as cash along with dividend payout in the form of shares (DPS).

$$
\begin{aligned}
D^{D P S} S_{i, t}=\alpha+\beta_{1} D P S_{i, t-1} & +\beta_{2} R C A P_{i, t}+\beta_{3} P R O_{i, t}+\beta_{4} L I Q U_{i, t}+\beta_{5} A G E_{i, t}+\beta_{6} F A M_{i} \\
& +\beta_{7} D E B T_{i, t}+\beta_{8} M V_{i, t}+\eta_{i}+\varepsilon_{i, t}
\end{aligned}
$$

The dependent variable DPS $i, t$ of the equation shows the cash per share + stock dividend payout per share in year $t$ of firm $i$. $R C A P_{i, t}$ shows the mathematical inverse of firm $i$ 's market capitalization in year $t, P R O_{i, t}$ shows firm $i^{\prime}$ 's return on equity in year $t, L I Q U_{i, t}$ shows firm $i$ 's liquidity ratio in year $t, A G E_{i, t}$ shows firm $i$ 's age in year $t, F A M_{i}$ represents a dummy variable indicating whether the firm $i$ is controlled by a family, $D E B T_{i, t}$ shows firm $i$ 's debt ratio in year $t, M V_{i, t}$ shows firm i's market value/book value in year $t, \eta_{i}$ shows unobservable firm effects, $\varepsilon_{i, t}$ shows the effect of unobservable cross section variables changing over time.

As in the above equation, models in which a lagged dependent variable $\left(D P S_{i, t-1}\right)$ is included as an independent variable are called dynamic models and these models are generally expressed in the form of the following equation (Güngör and Kaygın 2015):

$$
\begin{gathered}
Y_{i, t}=d Y_{i, t-1}+\beta X_{i, t}^{\prime}+u_{i, t} \\
i=1, \ldots, N t=1, \ldots, T \\
u_{i, t}=v_{i, t}+\mu_{i}
\end{gathered}
$$

In this model $\mu_{i}$ for the $i^{\text {th }}$ observation, since it is independent from $t$ as a constant (or in other words since $\mu_{i}$ doesn't change over time) is included in the model both as the dependent variable $\left(Y_{i, t}\right)$ as well as the model's the explanatory variable which is the lagged value $\left(Y_{i, t-1}\right)$, is a function of $\mu_{i}$. Because of the correlation between the lagged dependent variable and the error term, the least square estimates are biased (Greene 2003).

Dynamic panel data models are divided into two types (Greene 2003; Tatoğlu 2013): autoregressive panel data models in which the lagged values of the dependent variable are included as independent variables, and distributed lag panel data models in which the lagged values of the independent variables are included as independent variables. Arellano and Bond (1991) developed the Difference GMM method of dynamic panel estimation in order to solve the problems in auto-regressive models (Arr and Özcan 2011). Since the lagged values of the independent variables are used as an instrumental variable by taking the first differences of the variables in the development of this method, it's called the Difference GMM (Dökmen 2012). However, in the case of unbalanced panel data or when $T$ is small, there is data loss in the first difference transformation. For example, if there is no data for $Y_{i t}$, the data for $\Delta Y_{i t}$ and $\Delta Y_{i t-1}$ will be lost in the first difference transformation. Because of these problems, Arellano and Bover (1995)'s Difference GMM, an effective instrumental variable estimator, was developed using the Orthogonal Deviations Method. With this method, the difference between the current period and the previous period is not counted; instead the average of the future values of the variable is used. In this way, the data loss caused by the Difference GMM, especially in data sets which are especially unbalanced, is minimized. This method, which establishes equality between an original system and a transformed system and estimates them as one system together, is known as System GMM (Tatoğlu 2013). System GMM is based on combining the difference equation and the level equation and it has been proven that it has a proportionally higher estimation ability than the GMM (Dökmen 2012).

The estimation method of Arellano-Bover/Blundell-Bond, one of the system's GMM methods, two-step system GMM estimator for estimation in our equation is used. Considering that the panel data set is unbalanced and that $T$ is low with the algorithm developed by Roodman (2006). 


\section{Empirical Results}

In econometric analyses, the time series, the average and variance of which do not change over time, and also the covariance of which depends on the distance between the two periods only and not on the period of calculation, are called stationary series. In the System GMM Estimator, analysis is done under the assumption that the data are stationary. However, it is known that sometimes the data, including the panel data, are not stationary. If data is not stationary, the regression results may be spurious. In some cases, even dependent and independent variable are unrelated, it is possible to find a relationship between dependent and independent variables with high $\mathrm{R}^{2}$. For this reason, in order to understand the series' tendency, it is necessary to find the regression with the values of the previous period in the value of every series. One of the best known and most commonly used unit root tests is Dickey-Fuller test (Dickey and Fuller 1979). It is grounded on the model of the first-order autoregressive process (Box and Jenkins 1970):

$$
y_{t}=\varnothing_{1} y_{t-1}+\varepsilon_{t} \quad t=1, \ldots, T
$$

where $\varnothing_{1}$ is the autoregression parameter, $\varepsilon_{t}$ is the non-systematic component of the model that meets the characteristics of the random walk process. The null hypothesis is $H_{0}: \varnothing_{1}=1$ which means that that the process contains a unit root and consequently it is non-stationary, alternative hypothesis is $H_{0}:\left|\varnothing_{1}\right|<1$ which means that the process does not contain a unit root and is stationary.

After the model was established it was determined that all panel variables were stationary with the ADF-Fisher Chi-Square (Dickey and Fuller 1979); Im, Pesaran and Shin W (Im et al. 2003); Levin, Lin and Chu (Levin et al. 2002) and PP-Fisher Chi-Square (Phillips and Perron 1988) tests. Table 4 shows the results of the unit root tests applied to the variables at once.

Table 4. Results of Unit Root Tests Applied to the Variables.

\begin{tabular}{ccccccccc}
\hline & \multicolumn{2}{c}{ Levin, Lin \& Chu t } & \multicolumn{2}{c}{$\begin{array}{c}\text { Im, Pesaran and } \\
\text { Shin W }\end{array}$} & \multicolumn{2}{c}{$\begin{array}{c}\text { ADF-Fisher } \\
\text { Chi-Square }\end{array}$} & \multicolumn{2}{c}{$\begin{array}{c}\text { PP-Fisher Chi } \\
\text { Square }\end{array}$} \\
\cline { 2 - 9 } & Stat. & Prob. & Stat. & Prob. & Stat. & Prob. & Stat. & Prob. \\
\hline DPS & -32.5045 & 0.000 & -12.6831 & 0.000 & 522.653 & 0.000 & 643.941 & 0.000 \\
RCAP & -65.2300 & 0.000 & -20.1040 & 0.000 & 598.048 & 0.000 & 468.869 & 0.000 \\
PRO & -35.8009 & 0.000 & -8.73764 & 0.000 & 413.820 & 0.000 & 445.834 & 0.000 \\
LIQU & -30.5018 & 0.000 & -8.52122 & 0.000 & 424.381 & 0.000 & 430.383 & 0.000 \\
DEBT & -48.8429 & 0.000 & -6.68839 & 0.000 & 348.622 & 0.000 & 344.175 & 0.000 \\
MV & -25.8335 & 0.000 & -6.72648 & 0.000 & 384.629 & 0.000 & 401.920 & 0.000 \\
\hline
\end{tabular}

Note: If the probability value is less than $10 \%$, " $H_{0}$ : variable has unit root" is rejected. In other words, the variable is stationary.

As seen from Table 4, according to the four different unit root test statistics results, all of the variables used in the study are stationary. Therefore, according to these results, the stationary assumption required for the regression analysis is not violated.

As seen in the model, one of the explanatory variables $\left(D P S_{i, t-1}\right)$ which is the lagged of the dependent variable $\left(D P S_{i, t}\right)$. Many studies including Baltagi (2008), Greene (2003) and Anderson and Hsiao (1981) argue that dynamic panel data analysis should be utilized if the lagged of the dependent variable used as an explanatory variable in the model in order to estimate unbiased and consistent estimators.

Taking into consideration the arguments of Baltagi (2008), Greene (2003) and Anderson and Hsiao (1981) a dynamic panel estimation is used ${ }^{4}$. The results of the regression

4 Although this paper mainly focused on dynamic panel regression, pooled Ordinary Least Square (OLS) regression is carried out additionally. According to OLS regression results, the model is insignificant overall. The results of Maximum Likelihood 
using Arellano-Bover/Blundell-Bond two-step system GMM Estimator and the results are presented in the table below.

In Table 5, the test results provide information about consistency of the dynamic panel regression estimates. The Wald test is used to test the overall explanatory power of independent variables on the dependent variable, the Sargan and the Hansen tests reveal whether the instrumental variables are valid, and the Arellano-Bond $(A B)$ test is applied to detect the presence of the autocorrelation problem in the model.

Table 5. Two Step System GMM Dynamic Panel Regression Results.

\begin{tabular}{|c|c|c|c|}
\hline Variable & Coefficient & St. Dev. & $\mathbf{z}$ \\
\hline$D P S_{t-1}$ & $0.0162^{* * *}$ & 0.0010 & 15.39 \\
\hline$R C A P$ & $-3.2348^{* *}$ & 1.4464 & -2.24 \\
\hline PRO & $18.9507^{* * *}$ & 1.5120 & 12.53 \\
\hline$L I Q U$ & $0.1227 *$ & 0.0689 & 1.78 \\
\hline$A G E$ & 0.0060 & 0.0285 & 0.21 \\
\hline$F A M$ & 0.1501 & 2.4267 & 0.06 \\
\hline$D E B T$ & -5.6688 & 3.5416 & -1.60 \\
\hline$M V$ & $0.3810 * * *$ & 0.0592 & 6.44 \\
\hline \multicolumn{2}{|c|}{ Wald-Statistics } & $\operatorname{chi} 2(8)=1164.79$ & $\mathrm{P}>$ chi $2=0.000$ \\
\hline \multicolumn{2}{|c|}{ Arellano-Bond test AR(1) } & $z=-1.19$ & $\mathrm{P}>\mathrm{Z}=0.236$ \\
\hline \multicolumn{2}{|c|}{ Arellano-Bond test AR(2) } & $z=0.06$ & $P>z=0.951$ \\
\hline \multicolumn{4}{|c|}{ Instrumentals for First Difference Equality: D. (PRO. LIQU) } \\
\hline \multirow{2}{*}{\multicolumn{2}{|c|}{$\begin{array}{l}\text { Sargan test of overid. restrictions } \\
\text { Hansen test of overid. restrictions }\end{array}$}} & $\operatorname{chi} 2(21)=25.72$ & $\mathrm{P}>\mathrm{chi} 2=0.217$ \\
\hline & & $\operatorname{chi} 2(21)=21.83$ & $\mathrm{P}>\mathrm{chi} 2=0.410$ \\
\hline \multicolumn{4}{|c|}{ GMM Instrument Levels } \\
\hline \multicolumn{2}{|c|}{ Hansen test excluding group } & chi2(15) = 16.15 & $\mathrm{P}>$ chi $2=0.372$ \\
\hline \multicolumn{2}{|c|}{ Difference $\left(H_{0}=\right.$ exogenous $)$} & chi2 $(6)=5.68$ & $\mathrm{P}>\mathrm{chi} 2=0.460$ \\
\hline \multicolumn{4}{|c|}{ iv (PRO LIQU) } \\
\hline \multirow{2}{*}{\multicolumn{2}{|c|}{$\begin{array}{l}\text { Hansen test excluding group } \\
\left.\text { Difference ( } H_{0}=\text { exogenous }\right)\end{array}$}} & chi2(19) $=20.57$ & $\mathrm{P}>\mathrm{chi} 2=0.361$ \\
\hline & & $\operatorname{chi} 2(2)=1.26$ & $\mathrm{P}>\mathrm{chi} 2=0.534$ \\
\hline
\end{tabular}

The Wald test's hypotheses are:

$H_{0}=$ The independent variable has no explanatory power for the dependent variable.

$H_{1}=$ The independent variable has explanatory power for the dependent variable.

The $H_{0}$ hypothesis was rejected by Wald statistic's $(p<0.05)$, so the independent variables have explanatory power for the dependent variables and the whole model was concluded to be significant.

The Arellano-Bond test is employed to detect the autocorrelation problem in two-step system GMM regressions.

The Arellano-Bond test's hypotheses are:

$$
\begin{gathered}
H_{0}=\text { There is no autocorrelation. } \\
H_{1}=\text { There is autocorrelation. }
\end{gathered}
$$

The presence of 1st degree and 2nd degree autocorrelation was tested: The $A R(1)$ test came out statistically negative and insignificant, the $A R(2)$ test came out positive and insignificant. Therefore,

LR test results propose the pooled OLS regression over panel regression. The results of the pooled OLS regression show that estimation model is not correct. Additionally, Hausman test is applied to two-step system GMM and the test also favored two-step system GMM estimation over OLS. 
the $H_{0}$ hypothesis cannot be rejected for either equation. According to these findings, the conclusion was reached that there is no first- or second-degree autocorrelation. For the Generalized Moments Estimator to be effective, it is sufficient that there be no second degree autocorrelation (Tatoğlu 2013).

In the two-step system GMM dynamic panel regression, the Sargan (not robust) and Hansen (robust) tests as well as the over identifying restrictions validity test were performed to evaluate the validity of the instrumental variables. These Sargan test's hypotheses are:

$$
\begin{aligned}
& H_{0}=\text { The over identifying restrictions are valid for the instrumental variable. } \\
& H_{1}=\text { The over identifying restrictions are invalid for the instrumental variable. }
\end{aligned}
$$

The robust Difference-Hansen test's hypotheses are:

$$
\begin{gathered}
H_{0}=\text { The instrumental variables are exogenous. } \\
H_{\mathbf{1}}=\text { The instrumental variables are not exogenous. }
\end{gathered}
$$

According to both the Sargan (not robust) and the Hansen (robust) tests in the regression, the $H_{0}$ hypothesis cannot be rejected. Therefore, the over identifying restrictions are valid. Again according to the robust Difference-Hansen test results, the instrumental variables used as instrumentals are valid and the $H_{0}$ hypothesis level and GMM equalities cannot be rejected (Tatoğlu 2013).

As a result, the regressions that reveal the elements affecting the dividend payout decisions provide for the entirety of the conditions related to general significance, autocorrelation, and the instrumental variables.

When the dynamic panel regression results shown in Table 5 are examined on the basis of the independent variable the previous year's dividend payout $\left(D P S_{t-1}\right)$, the company's size $(R C A P)$, the return on equity $(P R O)$, the liquidity $(L I Q U)$, and the market value/book value ratio $(M V)$ are observed to have statistically significant with regards to their effect on the dependent variable included in the equation as DPS, cash/bonus dividend payout per share while the variables $A G E, F A M$, and $D E B T$ were not observed to have any statistically significant effect on dividend payout when shares given as a dividend were taken into account.

In our regression equation, the size of the company $(R C A P)$ is represented by the mathematical inverse of market capitalization [( 1 billion $\times$ Market Capitalization $)^{-1}$ ]. If there is a positive relationship between company size and dividend payout, it is expected that the correlation will be negative in the regression results as the indicator is its mathematical inverse. According to the regression results in Table 5, since the coefficient is observed to have a negative sign, therefore there is a 5\% positive correlation between company size and the dividend payout. According to the results, the one-tailed null hypothesis formulated as " $H_{0}=$ there is no positive relationship between company size and dividend payout" is rejected since the $z$-statistic value $(-2.24)$ is smaller than critical $\mathrm{z}$ value $(-1.645)$ for $\alpha=0.05$, and therefore the hypothesis $H_{1}$ is accepted. As a result, the size of company has a positive effect on the dividend payout. The conclusion reached is in line with previous works (Adaoglu 2008; Al-Kuwari 2009; Al-Malkawi et al. 2010; Denis and Osobov 2008; Fama and French 2001; Jensen et al. 1992; Kuzucu 2015; Y1ldiz et al. 2014) which conclude that there is a positive relationship between size of company and dividend payout.

In the regression equation, the variable indicating return on equity shown as $P R O$ is positive as expected. The company's return on equity has a significant effect on the dividend payout at the $1 \%$ significance level. According to these results, as the return on the equity increases, the dividends paid out by the companies also increase. This finding supports the free cash flow hypothesis developed by Jensen (1986) and is consistent with other studies in the literature (Ahmed and Javid 2008; Al-Ajmi and Hussain 2011; Al-Kuwari 2009; Al-Shubiri 2011; Ersoy and Çetenak 2015; Marfo-Yiadom and Agyei 2011; Patra et al. 2012) that found a positive relationship between profitability and dividend payout. 
The company's liquidity was represented by the ratio of Liquid Assets/Short-Term Liabilities. In the regression equation, the independent variable indicating liquidity shown by LIQU is positive as expected, and the relationship between the dependent variable and the independent variable has a $10 \%$ level of statistical significance. In other words, the result that the liquidity has a positive effect on the dividend payout ratio is in line with the study conducted by Yildiz et al. (2014) on the companies listed on the Borsa Istanbul.

The company's age, shown in the regression equations as AGE was not shown to have a statistically significant effect in relation to the dividend payout. For this reason, it is concluded that the company's age does not influence the dividend payout. The dummy variable FAM is used to test the hypothesis developed about the shareholder structure of the company and has a value of 1 if the company is controlled by a family, and 0 if not. According to the regression results in Table 5, the shareholder structure of the company has no effect on dividend payout.

Even though the coefficient of the independent variable shown as DEBT in the regression equation is negative, the effect of the company's debt ratio on dividend payout is not statistically significant. The market value/book value ratio, shown as $M V$, which represents growth opportunities of a company, has a positive significant effect on dividend payout at the $1 \%$ significance level.

In the regression, the coefficient of the previous year's dividend payout variable, as shown as $D P S_{t-1}$, is positive, as expected, and has a $1 \%$ statistically significant effect. According to the result, the one-tailed null hypothesis formulated as " $H_{0}=$ there is no positive relationship between current period dividend payout and the previous year's dividend payout" is rejected because the z-statistic value (15.34) is greater than the critical $\mathrm{z}$ value (2.33) for $(\alpha=0.01)$, and therefore the alternative hypothesis is accepted. In other words, as the previous year's dividend payout per share increases, the company's current period dividend payout as cash and/or bonus also increases. This conclusion supports Lintner (1956)'s hypothesis and is in line with studies (Al-Ajmi and Hussain 2011; Al-Najjar and Kilincarslan 2017; Al-Najjar 2009; Maldajian and Khoury 2014; Omet 2004) showing that the previous year's dividend payout ratio has a positive effect on the current period's ratio.

\section{Conclusions}

It can be said that decisions about how much of the end-of-period profit will be retained in the company and how much will be paid out to the shareholders have been made for about 400 years, since chartered companies emerged at the beginning of the 17th century. However, until the mid-20th century, there was general consensus that high ratio dividend had a positive impact on the value of the company (Frankfurter and Wood 1997). Miller and Modigliani (1961), with some simplifying assumptions, proposed that the value of the company (the share price) is not affected by the dividend payout decision or paying out more dividend will not necessarily increase the value of the company. Besides theoretical studies on dividend payout and empirical test of the hypotheses, many studies examine the factors affecting dividend payout at the company level.

In this study, 7 years of company data (2009-2015) was used to analyze the firm-specific factors affecting the dividend payout decisions of companies whose shares were traded on the Borsa Istanbul stock exchange between 2010 and 2016. The size of the company, profitability, liquidity, age, shareholder structure, debt ratio, market value to book value ratio and the previous year's dividend payout are taken as explanatory variables in the analysis. As a dependent variable, dividend paid out as shares (stock dividends) alongside dividend paid out as a cash are used jointly when calculating dividend payout per share.

According to the results of the dynamic panel regression; while the previous year's dividend payout per share (cash + stock dividend), return on equity, the market value to book value ratio, size (market capitalization), and the liquidity has a significant positive effect on dividend payout; there is no statistically significant relationship between the dividend payout and age, family control or debt ratio. 
Looking at the results of the regression, dividends paid out as cash and/or stocks are observed to be affected by the previous year's dividend payout. This situation shows that companies traded on the Borsa Istanbul have a target dividend payout ratio, like those on the New York Stock Exchange (Baker and Powell 2000), this rate hasn't changed much over the years, and they behave in a manner which support's Lintner (1956)'s dividend smoothing hypothesis.

In similar studies in the future, the development of different explanatory variables that may have an impact on dividend payout decisions, or the calculation of different proxies for variables which already exist in the literature, can help estimate of company's actions. In addition, the undertaking of similar studies using different samples from those used in this study (e.g., a sample including only banks and other financial institutions or companies that don't distribute any dividends at all) would contribute to the overall study of dividend payout decisions.

Author Contributions: Conceptualization, F.B., E.K. and G.S.; Methodology, F.B. and E.K.; Validation, F.B.; Formal analysis, F.B. and E.K.; Data curation, E.K.; Writing—original draft preparation, F.B. and E.K.; Writing-review and editing, F.B. and E.K.; Supervision, G.S.; project administration, E.K.

Funding: This research received no external funding.

Conflicts of Interest: The authors declare no conflict of interest.

\section{References}

Adaoglu, Cahit. 2008. Dividend Policy of the Istanbul Stock Exchange (ISE) Industrial Corporations: The Evidence Revisited (1986-2007). Journal of BRSA Banking and Financial Markets 2: 113-35.

Agyei, Samuel Kwaku, and Edward Marfo-Yiadom. 2011. Dividend Policy and Bank Performance in Ghana. International Journal of Economics and Finance 3: 202-7. [CrossRef]

Ahmed, Hafeez, and Attiya Yasmin Javid. 2008. Dynamics and Determinants of Dividend Policy in Pakistan (Evidence from Karachi Stock Exchange Non-Financial Listed Firms). International Research Journal of Finance and Economics 25: 148-71.

Al-Ajmi, Jasim, and Hameeda Abo Hussain. 2011. Corporate Dividends Decisions: Evidence from Saudi Arabia. The Journal of Risk Finance 12: 41-56. [CrossRef]

Alam, Md. Zahangir, and Mohammad Emdad Hossain. 2012. Dividend Policy: A Comparative Study of UK and Bangladesh Based Companies. IOSR Journal of Business and Management 1: 57-67. [CrossRef]

Al-Kuwari, Duha. 2009. Determinants of the Dividend Policy of Companies Listed on Emerging Stock Exchanges: The Case of the Gulf Cooperation Council (GCC) Countries. Global Economy E Finance Journal 2: 38-63.

Al-Malkawi, Husam-Aldin Nizar, Michael Rafferty, and Rekha Pillai. 2010. Dividend Policy: A Review of Theories and Empirical Evidence. International Bulletin of Business Administration 9: 171-200.

Al-Najjar, Basil. 2009. Dividend Behaviour and Smoothing New Evidence from Jordanian Panel Data. Studies in Economics and Finance 26: 182-97. [CrossRef]

Al-Najjar, Basil, and Erhan Kilincarslan. 2016. The Effect of Ownership Structure on Dividend Policy: Evidence from Turkey. Corporate Governance: The International Journal of Business in Society 16: 135-61. [CrossRef]

Al-Najjar, Basil, and Erhan Kilincarslan. 2017. Corporate Dividend Decisions and Dividend Smoothing: New Evidence from an Empirical Study of Turkish Firms. International Journal of Managerial Finance 13: 304-31. [CrossRef]

Al-Shubiri, Faris Nasif. 2011. Determinants of Changes Dividend Behavior Policy: Evidence from the Amman Stock Exchange. Far East Journal of Psychology and Business 4: 1-15.

Amidu, Mohammed, and Joshua Abor. 2006. Determinants of Dividend Payout Ratios in Ghana. The Journal of Risk Finance 7: 136-45. [CrossRef]

Anderson, Theodore Wilbur, and Cheng Hsiao. 1981. Estimation of Dynamic Models with Error Components. Journal of the American Statistical Association 76: 598-606. [CrossRef]

Andres, Christian, Markus Doumet, Erik Fernau, and Erik Theissen. 2015. The Lintner Model Revisited: Dividends Versus Total Payouts. Journal of Banking \& Finance 55: 56-69. [CrossRef]

Arellano, Manuel, and Stephen Bond. 1991. Some Tests of Specification for Panel Data: Monte Carlo Evidence and an Application to Employment Equations. The Review of Economic Studies 58: 277-97. [CrossRef] 
Arellano, Manuel, and Olympia Bover. 1995. Another Look at the Instrumental Variable Estimation of Error-Components Models. Journal of Econometrics 68: 29-51. [CrossRef]

Arı, Ayşe, and Burcu Özcan. 2011. İşçi Gelirleri Ve Ekonomik Büyüme Ilişkisi: Dinamik Panel Veri Analizi. Erciyes Üniversitesi İktisadi ve İdari Bilimler Fakültesi Dergisi 38: 101-17.

Baker, Kent H. 2009. Dividends and Dividend Policy. New York: John Wiley \& Sons.

Baker, Kent H., and Gary E. Powell. 2000. Determinants of Corporate Dividend Policy: A Survey of Nyse Firms. Financial Practice and Education 10: 29-40.

Baker, Malcolm, and Jeffrey Wurgler. 2004. A Catering Theory of Dividends. The Journal of Finance 59: $1125-65$. [CrossRef]

Baltagi, Badi. 2008. Econometric Analysis of Panel Data. New York: John Wiley \& Sons.

Benartzi, Shlomo, Roni Michaely, and Richard Thaler. 1997. Do Changes in Dividends Signal the Future or the Past? The Journal of Finance 52: 1007-34. [CrossRef]

Bernstein, Peter L. 1996. Dividends: Thepuzzle. Journal of Applied Corporate Finance 9: 16-22. [CrossRef]

Bhattacharya, Sudipto. 1979. Imperfect Information, Dividend Policy, and “the Bird in the Hand" Fallacy. The Bell Journal of Economics 10: 259-70. [CrossRef]

Black, Fischer. 1976. The Dividend Puzzle. The Journal of Portfolio Management 2: 5-8. [CrossRef]

Black, Fischer, and Myron Scholes. 1974. The Effects of Dividend Yield and Dividend Policy on Common Stock Prices and Returns. Journal of Financial Economics 1: 1-22. [CrossRef]

Box, George, and Gwilym Jenkins. 1970. Time Series Analysis-Forecasting and Control. San Francisco: Holden Day, $553 \mathrm{p}$.

Brawn, Derek A., and Aleksandar Šević. 2018. Firm size matters: Industry sector, firm age and volatility do too in determining which publicly-listed US firms pay a dividend. International Review of Financial Analysis 58: 132-52. [CrossRef]

Brealey, Richard A., and Stewart C. Myers. 2002. Principles of Corporate Finance. Boston: Irwin McGraw-Hill Education.

DeAngelo, Harry, Linda DeAngelo, and Douglas J. Skinner. 2009. Corporate Payout Policy. Foundations and Trends ${ }^{\circledR}$ in Finance 3: 95-287. [CrossRef]

Denis, David J., and Igor Osobov. 2008. Why Do Firms Pay Dividends? International Evidence on the Determinants of Dividend Policy. Journal of Financial Economics 89: 62-82. [CrossRef]

Dickey, David A., and Wayne A. Fuller. 1979. Distribution of the Estimators for Autoregressive Time Series with a Unit Root. Journal of the American statistical association 74: 427-31. [CrossRef]

Dökmen, Gökhan. 2012. Yolsuzlukların Vergi Gelirleri Üzerindeki Etkisi: Dinamik Panel Veri Analizi. Doğuş Üniversitesi Dergisi 13: 41-51.

Donaldson, Gordon. 1961. Corporate Debt Capacity. Cambridge: Harvard University Press.

Duygun, Meryem, Yilmaz Guney, and Abdul Moin. 2018. Dividend policy of Indonesian listed firms: The role of families and the state. Economic Modelling. [CrossRef]

Easterbrook, Frank H. 1984. Two Agency-Cost Explanations of Dividends. American Economic Review 74: 650-59. [CrossRef]

Ersoy, Ersan, and Emin Hüseyin Çetenak. 2015. Sahiplik Yogunlasmasinin Temettü Dagitim Kararlarina Etkisi: Borsa Istanbul'da Bir Uygulama/the Impact of Ownership Concentration on Dividend Payout Policy: Evidence from Turkey. Ege Akademik Bakis 15: 509-21. [CrossRef]

Fama, Eugene F., and Kenneth R. French. 2001. Disappearing Dividends: Changing Firm Characteristics or Lower Propensity to Pay? Journal of Financial Economics 60: 3-43. [CrossRef]

Frankfurter, George M., and Bob G. Wood Jr. 1997. The Evolution of Corporate Dividend Policy. Journal of Financial Education 23: 16-33.

Gordon, Myron J. 1959. Dividends, Earnings, and Stock Prices. The Review of Economics and Statistics 41: 99-105. [CrossRef]

Gordon, Myron J. 1963. Optimal Investment and Financing Policy. The Journal of Finance 18: 264-72.

Greene, William H. 2003. Econometric Analysis. Delhi: Pearson Education India.

Griffin, Carroll Howard. 2010. Liquidity and Dividend Policy: İnternational Evidence. International Business Research 3: 3-9. [CrossRef]

Grullon, Gustavo, Roni Michaely, and Bhaskaran Swaminathan. 2002. Are Dividend Changes a Sign of Firm Maturity? The Journal of Business 75: 387-424. [CrossRef] 
Günalp, Burak, and Tuncay Çelik. 2004. Türk Bankacılık Sektöründe Piyasa Yapısı Ve Performans İlişkilerinin Etkinlik İçin Doğrudan Bir Ölçüt Kullanılarak Test Edilmesi. Gazi Üniversitesi İktisadi ve İdari Bilimler Fakültesi Dergisi 6: 1-27.

Güngör, Bener, and Ceyda Yerdelen Kaygın. 2015. Dinamik Panel Veri Analizi Ile Hisse Senedi Fiyatini Etkileyen Faktörlerin Belirlenmesi. Kafkas Üniversitesi İktisadi ve İdari Bilimler Fakültesi Dergisi 6: 149-68. [CrossRef]

Im, Kyung So, M.Hashem Pesaran, and Yongcheol Shin. 2003. Testing for Unit Roots in Heterogeneous Panels. Journal of econometrics 115: 53-74. [CrossRef]

Javakhadze, David, Stephen P. Ferris, and Nilanjan Sen. 2014. An International Analysis of Dividend Smoothing. Journal of Corporate Finance 29: 200-20. [CrossRef]

Jensen, Michael C. 1986. Agency Costs of Free Cash Flow, Corporate Finance and Takeovers. American Economic Review 76: 323-29.

Jensen, Gerald, Donald Solberg, and Thomas Zorn. 1992. Simultaneous Determination of Insider Ownership, Debt, and Dividend Policies. Journal of Financial and Quantitative Analysis 27: 247-63. [CrossRef]

John, Kose, and Joseph Williams. 1985. Dividends, Dilution, and Taxes: A Signalling Equilibrium. The Journal of Finance 40: 1053-70. [CrossRef]

Kadioglu, Eyup, and Nurcan Öcal. 2016. Dividend Changes and Future Profitability: Evidence from the Turkish Stock Market. International Journal of Economics and Finance 8: 196-205. [CrossRef]

Kadioglu, Eyup, Niyazi Telçeken, and Nurcan Öcal. 2015. Market Reaction to Dividend Announcement: Evidence from Turkish Stock Market. International Business Research 8: 83-94. [CrossRef]

Kumar, B. Rajesh, and K. Abdul Waheed. 2014. Determinants of Dividend Policy: Evidence from GCC Market. Accounting and Finance Research 4: 17-29. [CrossRef]

Kuzucu, Narman. 2015. Determinants of Dividend Policy: A Panel Data Analysis for Turkish Listed Firms. International Journal of Business and Management 10: 149-60. [CrossRef]

Lasfer, M. Ameziane. 1996. Taxes and Dividends: The UK Evidence. Journal of Banking E Finance 20: 455-72. [CrossRef]

Levin, Andrew, Chien-Fu Lin, and Chia-Shang James Chu. 2002. Unit Root Tests in Panel Data: Asymptotic and Finite-Sample Properties. Journal of Econometrics 108: 1-24. [CrossRef]

Lintner, John. 1956. Distribution of Incomes of Corporations among Dividends, Retained Earnings and Taxes. American Economic Review 46: 97-113. [CrossRef]

Maldajian, Christopher, and Rim El Khoury. 2014. Determinants of the Dividend Policy: An Empirical Study on the Lebanese Listed Banks. International Journal of Economics and Finance 6: 240-56. [CrossRef]

Marfo-Yiadom, Edward, and Samuel Kwaku Agyei. 2011. Determinants of Dividend Policy of Banks in Ghana. International Research Journal of Finance and Economics 61: 99-108.

Miller, Merton H., and Franco Modigliani. 1961. Dividend Policy, Growth, and the Valuation of Shares. The Journal of Business 34: 411-33. [CrossRef]

Miller, Merton H., and Kevin Rock. 1985. Dividend Policy under Asymmetric Information. The Journal of Finance 40: 1031-51. [CrossRef]

Myers, Stewart C., and Nicholas S. Majluf. 1984. Corporate Financing and Investment Decisions When Firms Have Information That Investors Do Not Have. Journal of Financial Economics 13: 187-221. [CrossRef]

Nnadi, Matthias, Nyema Wogboroma, and Bariyima Kabel. 2013. Determinants of Dividend Policy: Evidence from Listed Firms in the African Stock Exchanges. Panoeconomicus 60: 725-41. [CrossRef]

Okumuş, Hacer Şaduman. 2002. Market Structure and Efficiency as Determinants of Profitability in the Turkish Banking Industry. Yapi Kredi Economic Review 13: 65-88.

Omet, Ghassan. 2004. Dividend Policy Behaviour in the Jordanian Capital Market. International Journal of Business 9: 287-300.

Papadopoulos, Dimitrios L., and Dimitrios P. Charalambidis. 2007. Focus on Present Status and Determinants of Dividend Payout Policy: Athens Stock Exchange in Perspective. Journal of Financial Management $\mathcal{E}$ Analysis 20: 24-37.

Patra, Theophano, Sunil Poshakwale, and Kean Ow-Yong. 2012. Determinants of Corporate Dividend Policy in Greece. Applied Financial Economics 22: 1079-87. [CrossRef]

Pettit, R. Richardson. 1977. Taxes, Transactions Costs and the Clientele Effect of Dividends. Journal of Financial Economics 5: 419-36. [CrossRef] 
Phillips, Peter C. B., and Pierre Perron. 1988. Testing for a Unit Root in Time Series Regression. Biometrika 75 : 335-46. [CrossRef]

Rehman, Abdul, and Haruto Takumi. 2012. Determinants of Dividend Payout Ratio: Evidence from Karachi Stock Exchange (KSE). Journal of Contemporary Issues in Business Research 1: 20-27.

Roodman, David. 2006. How to Do Xtabond2: An Introduction to Difference and System GMM in Stata. In Stata Journal 9: 83-136. [CrossRef]

Sayılgan, Güven, Hakan Karabacak, and Güray Küçükkocaoğlu. 2006. The Firm-Specific Determinants of Corporate Capital Structure: Evidence from Turkish Panel Data. Investment Management and Financial Innovations 3: 125-39.

Tatoğlu, Yerdelen Ferda. 2013. İleri Panel Veri Analizi Stata Uygulamalı. İstanbul: Beta Basım, Yayım, Dağıtım.

Vo, Duc Hong, and Thanh-Yen van Nguyen. 2014. Managerial Ownership, Leverage and Dividend Policies: Empirical Evidence from Vietnam's Listed Firms. International Journal of Economics and Finance 6: $274-84$. [CrossRef]

Walter, James E. 1963. Dividend Policy: Its Influence on the Value of the Enterprise. The Journal of Finance 18: 280-91. [CrossRef]

Yıldız, Berk, Rasim İlker Gökbulut, and Turhan Korkmaz. 2014. Firmalarda Temettü Politikalarını Etkileyen Unsurlar: Bist Sanayi İşletmeleri Üzerine Bir Panel Veri Uygulaması. AİBÜ-İ̈BF Ekonomik ve Sosyal Araştırmalar Dergisi 10: 259-92.

(C) 2018 by the authors. Licensee MDPI, Basel, Switzerland. This article is an open access article distributed under the terms and conditions of the Creative Commons Attribution (CC BY) license (http://creativecommons.org/licenses/by/4.0/). 